\title{
THE CHALLENGE OF OWNING THE RESULTS OF SCIENTIFIC RESEARCH IN ARGENTINA
}

\author{
Ester Elizabeth López Monrroy ${ }^{1}$
}

\begin{abstract}
The interaction of science with the problems of the society in which it is registered is fundamental. Argentina has been characterized through its history for its ability to produce knowledge, but also endemically has not been able to transfer that individual and collective investment to concrete solutions that, in addition, generate employment for the inhabitants of the country. In this context, what are the factors that obstruct this indispensable connection for national development? Thus, triangulation as a methodological strategy offers the study the possibility of obtaining a diagnosis of an extremely close situation. The current essential obstacle is in unison the lack of clarity that exists in relation to the role of the researcher and, in particular, the ethical commitment of a career that is financed with public funds. Limited clarity that is nourished by the same valid evaluation mechanisms.
\end{abstract}

Keywords: Transfer; Science; Technology and Industry.

\section{INTRODUCTION}

The core of the problem of the limited development of the Latin American region, in general, and of Argentina, in particular, is the absence of connection between Science, Technology and Industry despite a high local scientific capacity. The deficient fluidity of its transfer to technology and, later, to the industry causes the flight and the most alarming of this pernicious phenomenon is that it occurs as an effect of the same demands of the current evaluation process. The concrete result has been an isolated science, fragmented and little useful to society. Consequently, the promotion of a scholar or researcher based on publications instead of the impact of their work at the level of resolution of specific difficulties and/or patents of invention involves the dilution of the social benefit of the allocation of those resources and thus, exactly, evidenced by empirical data.

The evolution and revolution of scientific ideas that gives meaning and horizon to the concept of progress (BUNGE, 1994) it is thus decimated in the country, because that original work of theses and articles remains stagnant there, without achieving its purpose. This tends to crystallize systemic dependence, but above all invisible. Utility is a direct and immediate consequence of the objectivity of science, since it always foresees the 
application of the results of research, to such an extent that modern technology is increasingly applied science. Moreover, scientific research increasingly originates and justifies in the "context of application" of that knowledge, that is, the possibilities and expectations of its use (GIBBONS, 1995)

Scientific-technological research is a powerful tool for the transformation of a society. Science and technology are dynamic components of the very fabric of development; they are effect but also cause; they promote it but they also feed on it. (SABATO, 2011:215)

Sustainable development implies only the changes that have an internal genesis. Therefore, it is characterized by the implementation of new combinations. The key to innovation is employment differently from the natural and intellectual resources existing in a country. Thus, "to combine is to produce and to produce is to combine" (SCHUMPETER, 1941). The great transformation consists in the local accumulation of diverse forms of capacity, among them, especially knowledge. In this sense, it is particularly important the context in which these capacities are developed, because it is molded by the opportunities that the actors have to enter and operate in the different areas of technology. These opportunities reflect the intrinsic ease (prior natural aptitude) of imitation (STIGLITZ, 2014)

"The patent of invention is an instrument of industrial policy at the service of the development of the countries. The very basis of law is territorially and intimately linked to the sovereignty of the State" (LÓPEZ MONRROY, 2014). The utility derives from the disclosure of the technical instructions of the invention, but "if the learning processes are not important the national capacities are prone to disappear" (NACLEIRO, 2010). The industrial property regime of a country integrates the innovation system itself, because it does not exist independently. Above all, if one considers that each right has a correlative obligation and, therefore, exploiting the invention through local production is the very basis of the right to the patent. Thus, the importation of the product from a single external origin of production would cause an enrichment without cause of the owner, since it does not generate any benefit for the country that grants the patent. Thus, Brazil provides in its legislation the granting of a compulsory license in the absence of exploitation of the object of the patent in the Brazilian territory, either because it is not manufactured or that the manufacture is only partial of the product and, even, due to the absence of use of the patented process. ${ }^{2}$

The fundamental error is to try to fill the gaps on the tacit assumption that science is a kind of external input to the production system that, driven in the right way, can contribute powerfully to break the inertia of backwardness and dynamize a society essentially static. (HERRERA, 2011:157)

In this sense, it is essential to generate a system of interactions whose essential characteristic is the clarity of the endogenous nature of science, technology and industry in the sustainable development of the country. The ability to insert science in this continuous process is based on transferring this knowledge to the still embryonic

\footnotetext{
1 Pós-Doutorada em Política de Inovação Inclusive do CITCA (CONICET UNCa), Catamarca, Argentina. E-mail: esterelizabethlopezmonrroy@gmail.com.
} 
national industry. Therefore, one must be able to ignore the frontiers that produce time, ignorance and prejudices among the different instances of production that, in turn, all have as raw material for excellence to knowledge.

The case of César Milstein is perhaps the most emblematic and ostensible of all those advances that were made in the country and then migrated to other destinations in the world. Argentine chemist trained almost entirely in the public system, but induced by the political conditions of the country, particularly the military coup of 1962. The Medical Research Council, University of Cambridge, England received him with open arms and made it possible for him to continue his work on hybridomas that produce monoclonal antibodies, which are used today, for example, in the early detection of tumors. These studies earned him the Nobel Prize for Medicine in 1984. Although he did not register any patent in his name, his research resulted in a large number of patents. "On October 23, 1979, Hilary Koprowski patented the production of antibodies from tumor cells, and on April 1, 1980, the same researcher patented the production of antibodies against viral antigens." Something similar happened with the three-dimensional model of the antibody molecule, in which another Argentine, Roberto J. Polajk, had a leading role (GOLDSTEIN, 1989:99)

Now, what are the factors that obstruct this indispensable connection for national development? What Latin American critical thinking has made clear about science is that in general the region, but especially Argentina, are updated scientifically. They also stressed that while the scientific update is carried out in national universities with relative success, technological modernization follows a different path because it is done through simple import from abroad, with virtually no contribution to these innovations. This naive propensity for imitation was defined for study under the term "mimicry" towards the end of the 1960s (ALBORNOZ, 2011). Consequently, the balance between the technology acquired outside and that produced internally is, at least until now, heavily negative. The most eloquent indicator of this local reality is the balance of payments, whose red balance reaches many millions of dollars each year, amounts that are only diminished significantly when the price of basic production inputs increases due to a stifling indebtedness.

In this context, how is such a contrast possible between these three instances of the same reality, which common sense suggests complementary and dependent on one another? For this reason, it is essential to turn our attention to those concepts that, although crystallized in the conscience of both researchers and managers of the public, do not reflect the true nature of what science, technology and industry actually are. In this sense, it is essential to anticipate that work will be done with invention patents, as well as indicators, because it is considered that they are in all instances of the same progress, that is, science, technology and industry. In addition, what is meant by innovation is what his mentor, Joseph Alois Schumpeter, understood as such, that is, the combination of what exists for the creation of the new. Consequently, it is not an entity in itself but simply a quality that must

\footnotetext{
${ }^{2}$ Article 68, paragraph I of Law 927 of Brazil.
} 
necessarily contain each of those instances.

\section{SCIENCE AS A CAUSE OF THE GENESIS OF DEVELOPMENT}

In Argentina, it must be based on the premise that development is based on science, in order to overcome the conceptual error of believing that it is the State that supports science because it "looks good", that part of the budget is destine to her, although it is not clear for what it is. Here is the historical tension between science for development or revolution, that is, the origin of causality: countries are rich because they invest in science or, on the contrary, because they are rich they allow themselves "luxury" to spend on science? (KREIMER, 2015)

The clarity of knowing whether it is an investment or an expense is inextricably linked to the understanding of the reality involved in that definition and a country project. Logically, if you do not have a common horizon that generates social awareness of its importance as a value, it will be an expense, an ostentation that will make any present urgency more relevant. However, if it is able to generate awareness as Sarmiento did to unite education of excellence to one's own identity and articulate the mechanisms to assemble these three stages of the same process to achieve adding value to national production it will be an investment in the short, medium and long term.

The mismatch is due to our mistaking the technological style. Or rather, we try to appropriate an alien style. Thus, a scaffolding has been created in Argentina that far from benefiting, harms the country, because it evaluates the researchers for publications with a higher score if it is an individual endeavor and in another language -exporting valuable raw material-, which besides not generate the smallest redito, you must pay the magazine; technology is imported on which there are great possibilities of local production; and, in addition, the legal basis of this scaffolding has been developed with standards that facilitate the use by foreign companies instead of strengthening small and medium-sized local businesses.

"Any large or small society, simple or complex, has a system or process that works to usefully transform the resources that nature and previous generations have provided." The production possibilities frontier (PPF) is a graphic representation of the maximum production quantities that an economy can obtain in a given period making use of all the available resources. However, if not all available resources were used, that is, the potential production would not be reached, the quantities produced will be inside the enclosure delimited by the PPF. Consequently, they would be at a possible but inefficient level. ${ }^{3}$

A highly damaging instrument for local development is the total absence of exploitation requirement in

\footnotetext{
3 https://es.slideshare.net/Gunther_vb/frontera-de-posibilidades-de-produccin-fpp-8598852, its extensive reading is recommended.
} 
the territory of the invention protected by patent, thus a right is granted that is used only to restrict the use in the country. Therefore, simple importation from some external source of production implies exploitation for a reading circumscribed to the Agreement on Trade-Related Aspects of Intellectual Property Rights (TRIP's). However, the richness of the constitutional evolution that has as its center the human right to development is forgotten, therefore, any international treaty that violates that right is simply unconstitutional.

To feel that it is reflected in the clause of progress of Article 75, paragraph 18 of the National Constitution, arguing that it corresponds to the Congress" to provide what is conducive to the prosperity of the country, to the advancement and welfare of all the provinces, and to the progress of the illustration...". This subsection is complemented with the 19 incorporated after the 1994 reform, because it must also provide "... what is conducive to human development, economic progress with social justice, the productivity of the national economy, the generation of employment, the professional training of workers..., scientific and technological development, its dissemination and use... and even balance the uneven relative development of provinces and regions.... (LÓPEZ MONRROY, 2017:2)

In this context, there is no doubt that in order to connect science with technology and both with industry, we must intervene with the delicacy provided by the knowledge produced by the science asylum, that is, the social sciences. Organize in such a way that they are articulated so that they can function in a correct way, without that sensation of atrophy that is perceived every time that one tries to deepen in, for example, something as crucial as it is why it does not generate employment in Argentina. A country of an extension and quality in its soil, but even more in its people because studies have shown that with less or equal investment in $R \& D$, greater products are obtained (LÓPEZ MONRROY, 2014)

Nourishing the diagnosis of knowledge built in the country is perhaps the greatest challenge today, but also the most urgent. Especially if one thinks that the sharp separation that is sought from the instances comes from the influence of exogenous science, since it attempts to "present the exact sciences as the archetype and the researchers always separated from the world by the walls of their laboratories, as if the only way to study the world scientifically was by bits and in controlled conditions, in vitro" (VARSAVSKY, 1969:8)

The postponement of a society that generates underdevelopment is because it is functional to the scientific lordship of the developed, because the limitation goes beyond the temporal to imitate them. "Hence, the scientist must be constituted by an ethical dilemma that in no way detracts from the universalism of his science". The ethics that permeates this approach is completed with the idea that technological development is not the same in the hegemonic countries as in the backward countries, since one of the roots of this delay is precisely the mimetic impulse that leads them to replicate the central scientific mode (HERRERA, 2011). Wellness that is no longer possible to glimpse without the necessary integration of the political, economic and social objectives of the countries of the region.

The impediments that exist in Argentina for sustainable development are cultural and not scientific, technological or industrial, as it is often asserted, since there are plenty of resources for a more logical articulation 
and link between the different instances. In particular, if the emphasis is placed on the fact that the financing of a researcher's daily task comes from his compatriots and, therefore, it is those people to whom specific answers must be given. The characteristics of the research in Argentina also define the meaning, not just the work topics. No one ignores individual merit, however a favorable situation for access to education coupled with the possibility of working that highlights the vocation of the researcher. Therefore, we must be grateful and, fundamentally, have a serious ethical commitment to development. So essential is this truth that each researcher is more efficient doing what he likes and for what, in many cases, he has prepared all his life. Therefore, the importance of forming managers of excellence that enable this articulation, so that no researcher should run the task that makes him happy to perform.

\section{TRANSFER BETWEEN SCIENCE, TECHNOLOGY AND INDUSTRY}

"Calling transfer to what is commerce is like calling love to what is prostitution" (SABATO, 2011:235). The essential component of technology is scientific knowledge. Technology has a strategic value, to the point that it is central for countries or companies to have it or not. "The artisan production of a technology becomes industrial production as the amount of scientific knowledge increases" (SABATO, 2011:312)

The chain of events constitutes a continuous succession in which these three links feed back on each other, even those that at first sight seem further away and, therefore, prototypes can force changes in knowledge itself. Even more: to look for new results in the law or theory and this is how the plot linking science, technology and its consequent reproduction on an industrial scale is articulated (SABATO, 2011:313)

The production of technology is carried out in factories, that is, research and development laboratories. "They are true factories because their objective is also to produce a good: technology" (SABATO, 2011: 315). Consequently, there must be a constant chain of connections between creation, transfer -diffusion- and utilization so that the fruits of scientific research become technology, when they are effectively incorporated into the production and distribution process of goods and services. "In summary: the technical development process is not established as such if the three stages are not carried out in a balanced and interrelated way" (HALTY, 2011:348)

In the same sense, it is stated that "just as the constituent element of economic development is not the creation of wealth, but the ability to create wealth, it is not enough to foster technical progress, it is necessary to lay the foundations to create technical progress". Thus, the power of decision, realization and control of a selfpropelled technical progress is fundamental. Progress that is only possible if technical development is achieved, coordinated with an industrial development policy and integrated into a general development policy (HALTY, 2011:347) 


\section{Figure I: Transfer Process}

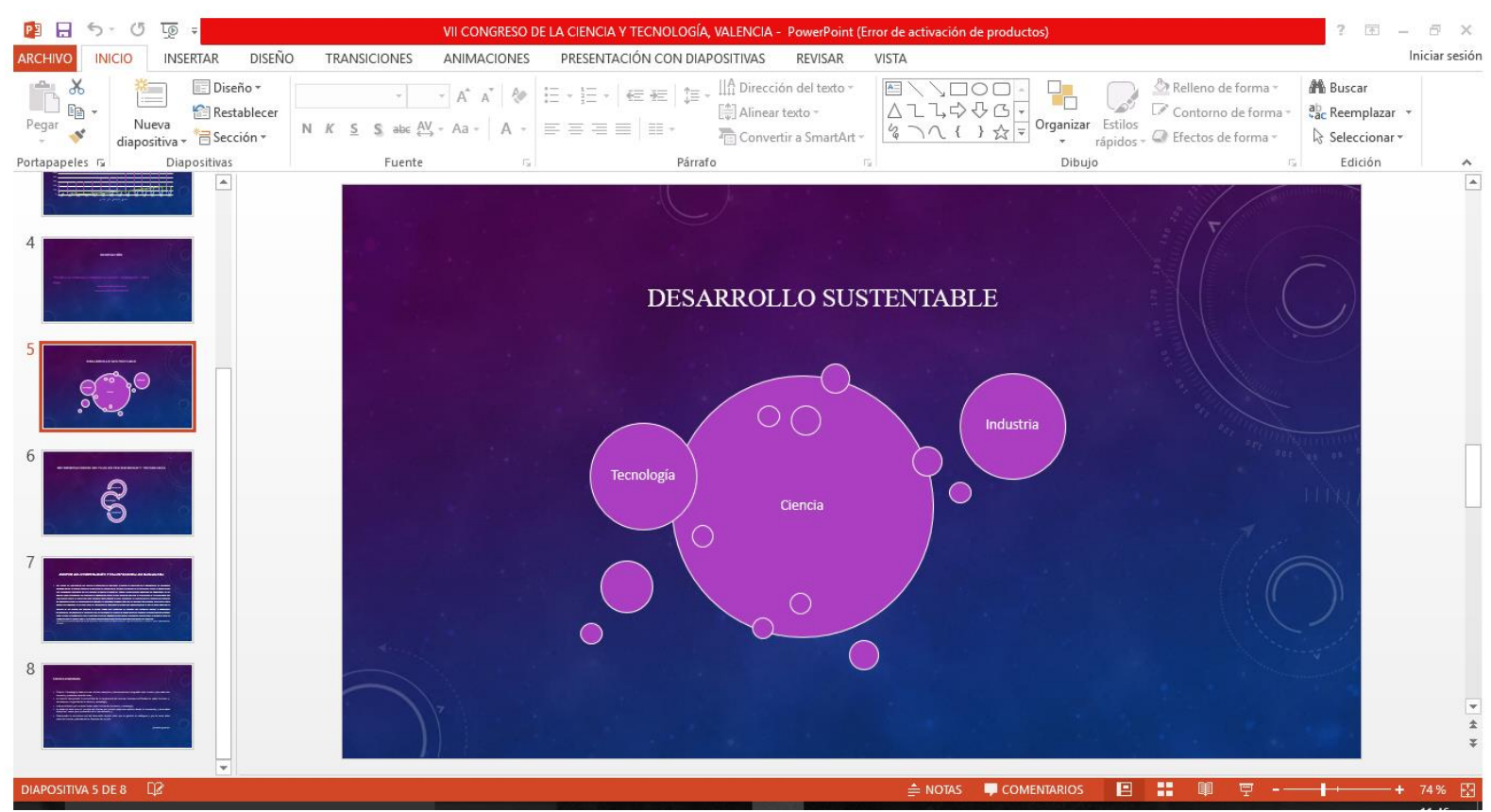

Source: own elaboration for the VII International Congress of Science, Technology and Society in Valencia, Spain.

However, specifically how many jobs have been lost in Argentina due to the lack of understanding of these concepts. For this, indicators are essential, because they accurately reflect the relationship between inputs and products, as well as the level of innovation in the country and its comparison with the rest of the world. In particular, the Latin American region.

\section{Figure II: Indicators of Inputs and Products for Argentina}

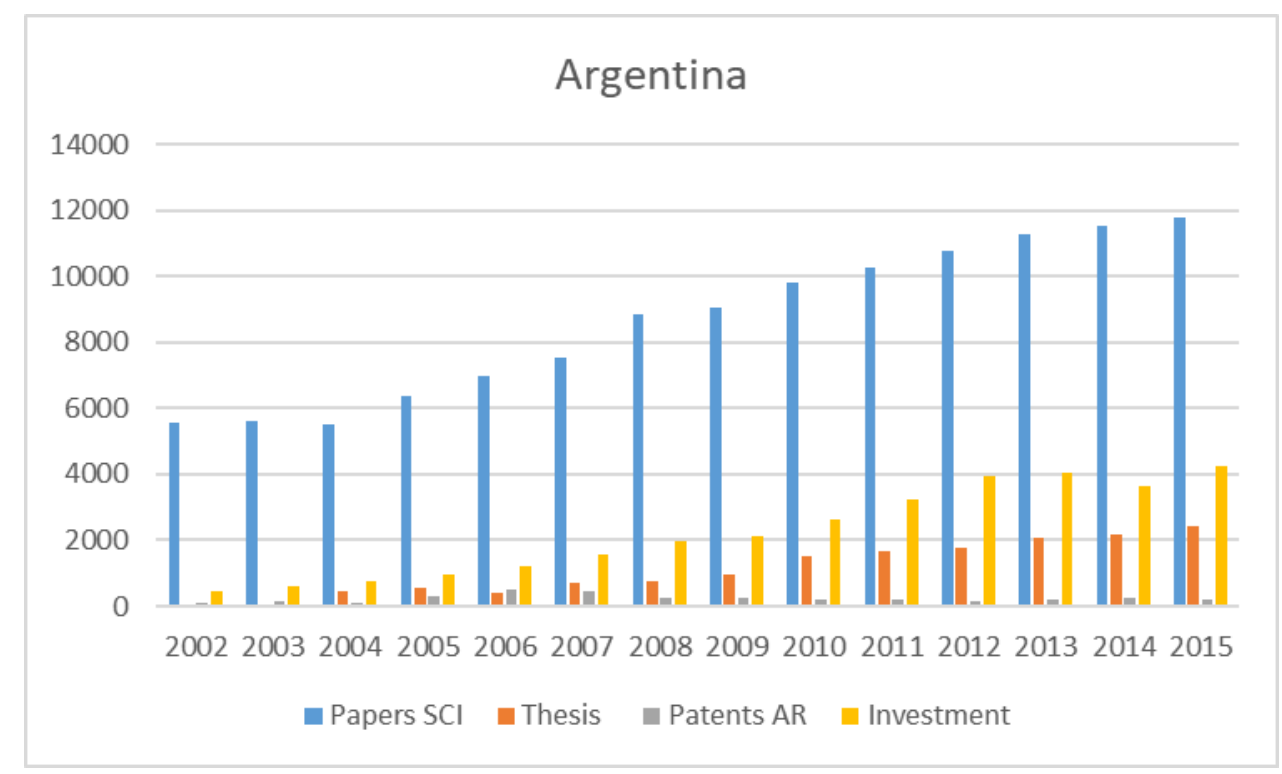

Source: own elaboration based on data from the Red Iberoamericana de Indicadores en Ciencia y Tecnología (RICYT) 
The indicator used for the articles is based on the Science Citation Index (SCI), since it includes all the contributions that can be published to the science and technology journals indexed by Thomson Reuters. This publication contains practically all areas of knowledge, including the social sciences. However, this contribution is to a lesser extent and although it may seem a bias of the sample because it has no direct practical application, if only the exact areas of science are taken, the result is similar. Fact that can be observed in the disaggregation of the data of the graphs presented below:

\section{Figure III: Articles and Doctoral Theses in Exact Sciences}

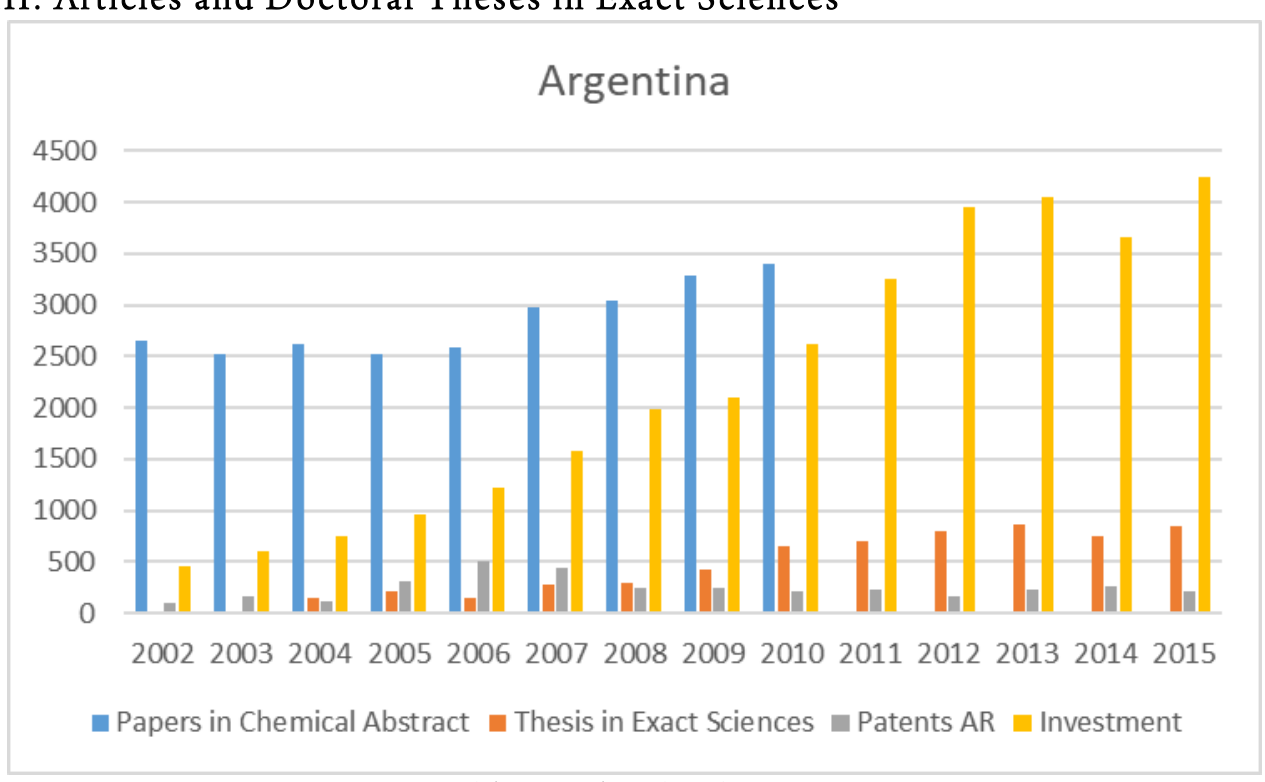

Source: own elaboration based on data from the RICYT

In the graphic above it can be observed -for the years for which information is available- the impressive difference that exists between publications and theses in exact sciences, particularly the chemical area; with the total sum of patents granted to residents in Argentina without discriminating by field of technology, because if you do that directly you would not see anything in the place of that data 


\section{Figure IV: Articles and Theses of Doctorate in Medicine}

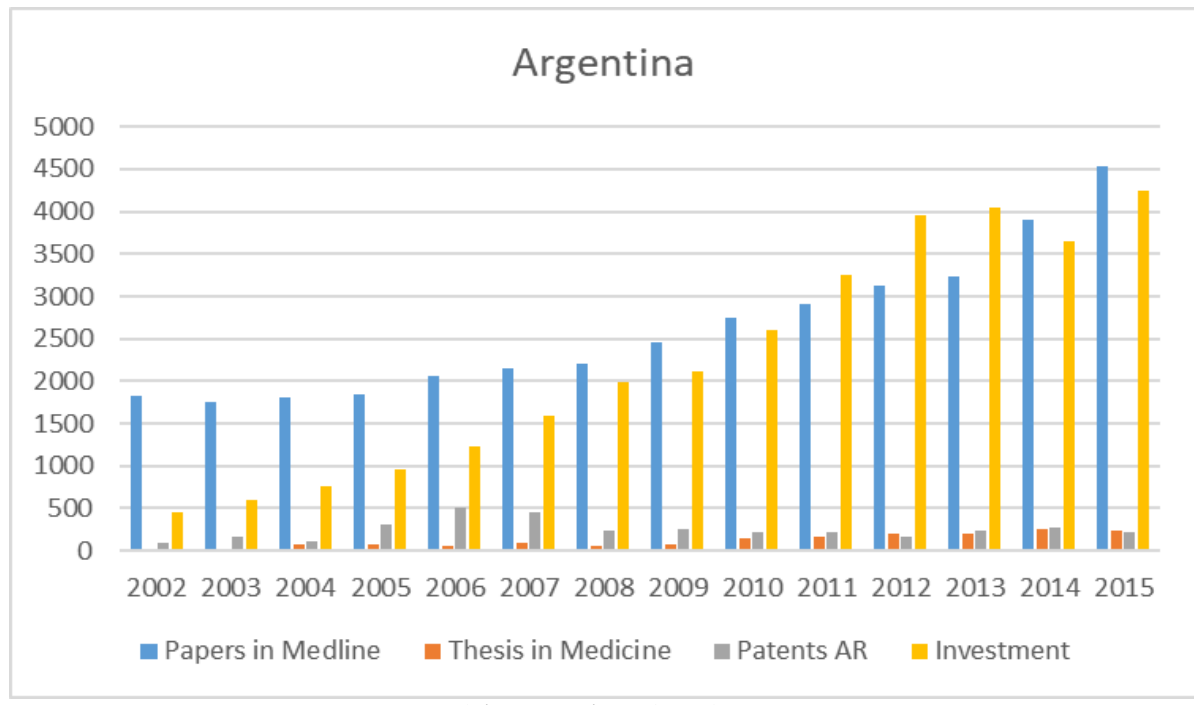

Source: own elaboration based on data from RICYT

In conclusion, we could continue with each of the areas directly related to the patents of invention and we would obtain an identical result. The reason is simple, it has been consciously chosen to prioritize the evaluation of the researchers, but not to unite that knowledge with a local development strategy.

If the focus is transferred to the innovation indicators, that is, coefficient of invention, dependency rate and self-sufficiency rate for the region, the image of the level of dependence that exists outside is also frightening.

$\mathrm{SCI}$ is used as a relevant indicator because it takes contributions from different areas of knowledge, but fundamentally those related to the exact sciences indexed by Thomson Reuters. Although the presence of social sciences in the sample can be read as a research bias. The disaggregation of the data of the graphs for, for example, engineering materials Compendex (Elsevier), which is presented below confirms again this specific hypothesis: 


\section{Figure V: Articles on Materials Engineering published in Compendex}

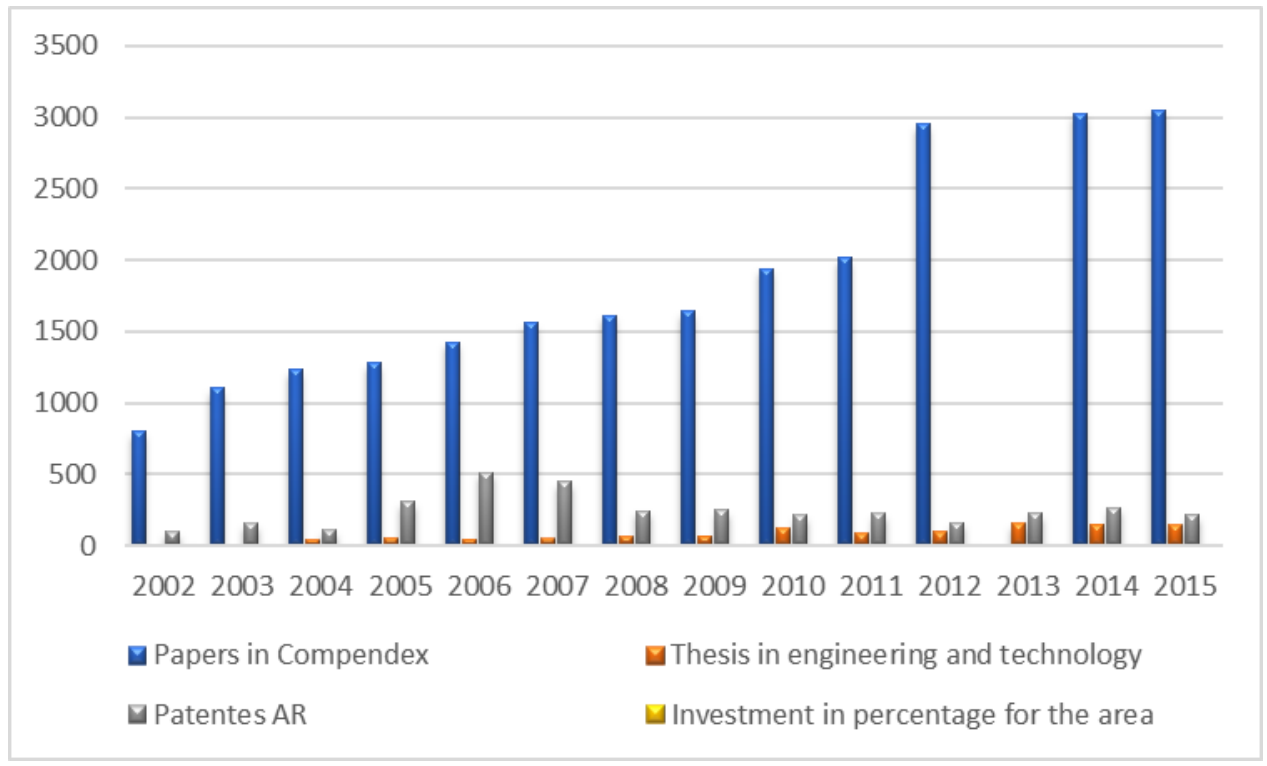

Source: own elaboration based on data from RICYT

\section{Figure VI: Innovation Indicators for 2014}

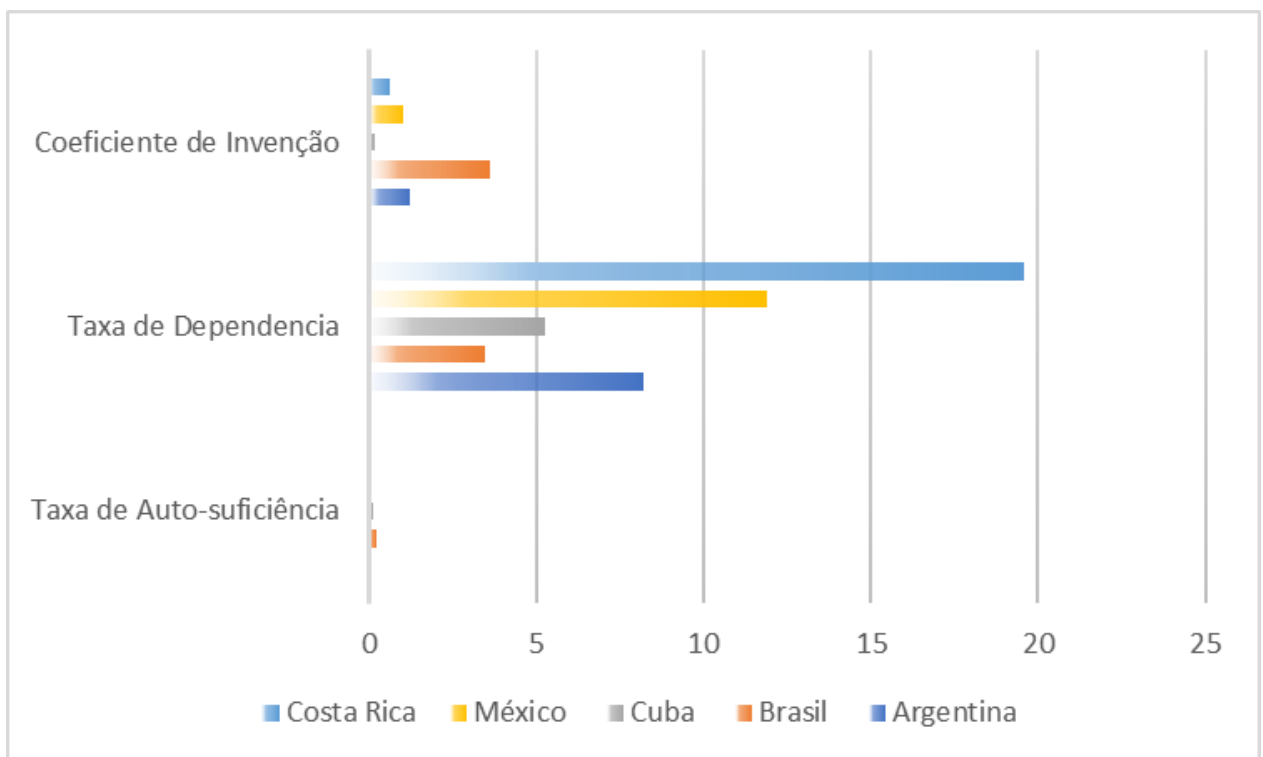

Source: own elaboration based on RICYT data published in Apropriação social do conhecimento na Argentina, Âmbito Jurídico.

Now, what is the cause of this loss of knowledge? In the elaboration of this transdisciplinary work it was possible to identify that the initial ideological rejection of the investigators is based in the totality of the cases in the ignorance about their content. Lack of knowledge that is consolidated with the institutional requirement of career evaluation primarily by articles. 


\section{CONCLUSION}

Sabato was able to say that it is important to have researchers in the country who care about the truth, but even more so if they use it to transform reality. For this reason, the evaluation of their work can definitely not be for an individual work and without first pondering the practical application of that knowledge. In this sense, all sciences enjoy the same "impact factor" in solving local problems. Therefore, it is where the accent should be placed, as a researcher aware that his task can help generate Argentine jobs and for Argentines will make the difference from now on.

Nourishing the state and public policy of knowledge built in the country is undoubtedly a necessary mission to be undertaken urgently. All the fruit of social research has an intrinsic richness to elaborate interesting models of interaction, in order to overcome the challenges contained in the situation diagnosis presented in this article.

The knowledge of the own strong and weak points associated to the analysis of the aforementioned hypotheses will contribute to the conception of a new political line in the national strategy in science, technology and industry capable of overcoming the current difficulty of the interaction between these instances of The same process exists in Argentina. Thus, throughout the text, an attempt was made to highlight how different cultures coexist in relation to an identical development process for the country.

In a scenario of limited development marked by the lack of diversification and differentiation of products and processes, a constant of all the diagnoses published through the different plans in Science and Technology, it is essential to unite the industry with the scientific and academic centers, in order to achieve more and better living conditions for all the inhabitants of the country.

\section{O DESAFIO DA PROPRIEDADE DOS RESULTADOS DA PESQUISA CIENTÍFICA NA ARGENTINA}

\section{Resumo}

A interação da ciência com os problemas da sociedade em que está registrada é fundamental. A Argentina tem sua história caracterizada pela sua capacidade de produzir conhecimento, mas também endemicamente não tem conseguido transferir esse investimento individual e coletivo para soluções concretas que, além disso, poderiam gerar emprego para os habitantes do país. Nesse contexto, quais são os fatores que impedem essa conexão indispensável para o desenvolvimento nacional? Assim, a triangulação como estratégia metodológica oferece ao estudo a possibilidade de obter um diagnóstico de uma situação extremamente próxima. O obstáculo essencial atual é, em uníssono, a falta de clareza que existe em relação ao papel do pesquisador e, em particular, o compromisso ético de uma carreira que é financiada com recursos públicos. Clareza limitada que é nutrida pelos mesmos mecanismos de avaliação válidos. 
Palavras-chave: Transferência; Ciência; Tecnologia e Indústria.

\section{BIBLIOGRAPHY}

ALBORNOZ, M.; BARRERE, R.; BAGENETA, M.; CHARREAU, H.; LÓPEZ MONRROY, E. E.; MATAS, L. (2008): Nanotecnología: Tendencias recientes en I+D. Argentina en el contexto internacional; disponible en www.caicyt.gov.ar

ALSINA, F. (2011): Investigación, transferencia, tecnología. En el pensamiento latinoamericano en la problemática ciencia-tecnología-desarrollo-dependencia. - 1a ed. - Buenos Aires: Ediciones Biblioteca Nacional.

BAYER G. (2011): Autonomía nacional y política científica y tecnológica. En el pensamiento latinoamericano en la problemática ciencia-tecnología-desarrollo-dependencia. - 1a ed. - Buenos Aires: Ediciones Biblioteca Nacional.

CHANG CASTILLO, H. (2010): El modelo de la triple hélice como medio para la vinculación entre universidad y empresa, Revista Nacional de Administración, Costa Rica.

CODNER, D. G., BECERRA, P., \& DÍAZ, A. (2012): Blind Technology Transfer or Technological Knowledge Leakage: a Case Study from the South. Journal of technology management \& innovation, 7(2), 184-195.

CORIAT, B. y ORSI, F. (2005): Are strong patents beneficial to innovative activities, Industrial and Corporate Change, Volume 14, Number 6.

CORREA, C. (1999): Derecho de Patentes, Ciudad Argentina, Buenos Aires, Argentina.

ESCUDÉ, C. (1986): La Argentina vs. Las Grandes Potencias. El precio del desafio, Buenos Aires, Editorial de Belgrano.

FIELDING, N., and FIELDING, J. (1986): Linking data: the articulation of qualitative and quantitative methods in social research, Beverly Hills, London, Stage.

GIBBONS, M. (1995): La nueva producción del conocimiento, Barcelona, Pomares-Corredor.

GOLDSTEIN, D. (1989): Biotecnología, Universidad y Política, Siglo XXI editores, México.

HALTY, M. (2011): Producción, transferencia y adaptación de tecnología industria. En el pensamiento latinoamericano en la problemática ciencia-tecnología-desarrollo-dependencia - la ed. - Buenos Aires: Ediciones Biblioteca Nacional.

HAMMERSLEY M., and ATKINSON, P. (1983): Ethnography: Principles in Practice, London, Tavistock.

HERRERA A. (2011): Los determinantes sociales de la política científica en américa latina. Política científica explícita y política científica implícita. En el pensamiento latinoamericano en la problemática ciencia-tecnologíadesarrollo-dependencia. - 1a ed. - Buenos Aires: Ediciones Biblioteca Nacional.

HURTADO, D. (2010): La ciencia argentina. Un proyecto inconcluso 1930-2000, Buenos Aires, EDHASA. 
JAGUARIBE H. (2011): Por qué no se ha desarrollado la ciencia en américa latina. En el pensamiento latinoamericano en la problemática ciencia-tecnología-desarrollo-dependencia. - 1a ed. - Buenos Aires: Ediciones Biblioteca Nacional.

KATZ J. (2011): Patentes, corporaciones multinacionales y tecnología. Un examen crítico de la legislación internacional. En el pensamiento latinoamericano en la problemática ciencia-tecnología desarrollo-dependencia. la ed. - Buenos Aires: Ediciones Biblioteca Nacional.

LÓPEZ MONRROY, E. E. (2014): Política de Estímulo a la Innovación: Patentes de Invención como instrumento Estratégico en Ciencia y Tecnología, Tesis de Doctorado, Universidad Nacional de Quilmes.

LÓPEZ MONRROY, E. E. (2015): Política de la Innovación Inclusiva, Ed. Universidad Nacional de Catamarca, Argentina.

MONZA A. (2011): La teoría del cambio tecnológico y las economías dependientes. En el pensamiento latinoamericano en la problemática ciencia-tecnología-desarrollo-dependencia. - 1a ed. - Buenos Aires: Ediciones Biblioteca Nacional.

NACLEIRO, A. (2010): Innovation system and developing countries: the Argentine's failure. Int. J. Techonology and Globalisation, Vol. 5. Nos 1/2, pp. 132-160.

SABATO, J. (1981): La Pampa Pródiga. Claves de una frustración: el agro pampeano argentino y la adopción de tecnología entre 1950 y 1978. Un análisis a través del cultivo del maíz, Centro de Investigaciones Sociales del Estado y la Administración.

SABATO, J. A. (2011): El pensamiento latinoamericano en la problemática ciencia-tecnología desarrollodependencia - 1a ed. - Buenos Aires: Ediciones Biblioteca Nacional.

SABATO, J. A., (1997): Bases para un régimen de tecnología. Redes, 4(10)

SABATO, J. y BOTANA, N. (1970): La ciencia y la tecnología en el desarrollo de América Latina", Tiempo Latinoamericano, Santiago de Chile, Editorial Universitaria.

SCHUMPETER, J. A., (1941): Teoría del Desarrollo Económico, London: Harvard University Press.

STIGLITZ, J. (2014): Intellectual Property Rights, Ed. Oxford.

VARSAVSKY, O. (1969): Ciencia, Política y Cientificismo. Buenos Aires: CEAL.

WADE, R. H. (2003): What strategies are viable for developing countries today? The World Trade Organization and the shrinking of development space, London.

WIONCZEK M. (2011): Hacia la racionalización de la transferencia de tecnología a México. En el pensamiento latinoamericano en la problemática ciencia-tecnología-desarrollo-dependencia - 1a ed. - Buenos Aires: Ediciones Biblioteca Nacional. 
Quaestio Iuris

Trabalho enviado em 27 de fevereiro de 2018.

Aceito em 21 de março de 2018. vol. 11, n. 02, Rio de Janeiro, 2018. pp. 1073 - 1086 DOI: $10.12957 /$ rqi.2018.32982 